\title{
Sistem Pakar Untuk Mendiagnosis Penyakit Pada Ikan Koi Dengan Menggunakan Metode Forward Chaining Berbasis Android
}

\author{
*Faisal Reza Sugma Prawira'), Rinabi Tanamal') \\ ${ }^{1,2}$ Information System for Business, Fakultas Teknologi Informasi, Universitas Ciputra \\ Correspondence author: Rinabi, r.tanamal@ ciputra.ac.id, Surabaya, Indonesia
}

DOI: https://doi.org/10.37012/jtik.v7i2.567

\begin{abstract}
Abstrak
Ikan Koi adalah tipe ikan hias yang banyak diminati oleh para penghobi ikan dan sangat populer di Indonesia. Tidak dapat dipungkiri bahwa selama beberapa tahun ini, ikan hias jenis Koi telah menjadi primadona ikan hias di Indonesia. Namun, ikan Koi sendiri merupakan makhluk hidup yang juga akan terpapar penyakit. Masalah utama yang selalu dihadapi oleh pembudidaya dan penghobi ikan Koi adalah penyakit, dan penyakit pada ikan Koi dapat menyebabkan kematian jika tidak dilakukan penanganan dengan benar. Ditambah lagi jumlah dokter di Indonesia sangat terbatas sehingga dibutuhkan perancangan sistem pakar untuk membantu pembudidaya dan penghobi ikan Koi dalam mendiagnosis penyakit ikan Koi. Metode yang digunakan dalam perancangan sistem pakar adalah forward chaining. Forward chaining digunakan untuk merumuskan kesimpulan menjadi sebuah keputusan. Oleh sebab itu penelitian yang dilakukan ini menghasilkan sebuah aplikasi berbasis Android yang bisa mendiagnosis penyakit ikan Koi. Aplikasi ini dirancang menggunakan metode forward chaining dengan menggunakan software aplikasi Thunkable. sumber pengetahuan penyakit ikan Koi didapatkan dari hasil wawancara dan pengamatan yang dilakukan bersama pakar guna membantu pembudidaya dan penghobi ikan Koi dalam mendiagnosis penyakit ikan Koi serta solusi penanganan penyakit tersebut.
\end{abstract}

Kata Kunci: Ikan Koi, Penyakit Ikan Koi, Sistem Pakar, Forward chaining, Thunkable, Android.

\begin{abstract}
Koi fish is a type of decorative fish that is in great demand by fish hobbyists and very popular in Indonesia. It is undeniable that for the last few years, Koi fish have become the prima donna of decorative fish in Indonesia. However, Koi fish themselves are living beings that also can be exposed to disease. The main problem faced by Koi fish cultivators and hobbyists is Koi fish disease that can cause death to the Koi fish if not handled properly and the number of veterinarian in Indonesia is very limited so an expert system designed to assist Koi fish cultivators and hobbyists in diagnosing Koi fish diseases is needed. The method used in designing expert systems is forward chaining. Forward chaining is used to formulate a conclusion into a decision. Therefore, this research has resulted in an Android based application that can diagnose Koi fish disease. This application is designed using the forward chaining method using the Thunkable application software. The source of knowledge of Koi fish diseases is obtained from the results of interviews and observations conducted with experts to help Koi fish cultivators and hobbyists in diagnosing Koi fish diseases and solutions for handling those diseases.
\end{abstract}

Keyword: Koi Fish, Koi Fish Disease, Expert System, Forward Chaining, Thunkable. 


\section{PENDAHULUAN}

Ikan Koi adalah tipe ikan hias yang banyak diminati oleh para penghobi ikan dan sangat populer di Indonesia. Tidak dapat dipungkiri bahwa selama beberapa tahun ini, ikan hias jenis Koi telah menjadi primadona ikan hias di Indonesia (Kusrini et al., 2015).

Ikan Koi sendiri merupakan makhluk hidup yang juga akan terpapar penyakit. Masalah utama yang selalu dihadapi oleh pembudidaya dan penghobi ikan Koi adalah masalah penyakit (Yanuhar et al., 2019). Terdapat beberapa factor pemicu munculnya penyakit yaitu tentang cuaca, kondisi kolam, lingkungan, pakan, dan faktor lainnya. Dengan demikian penyakit ini dapat menyebabkan kerugian, karena menghambat dalam segi pertumbuhan ikan, periode pemeliharan semakin lama, tingginya penggunaan pakan, dan kematian ikan tersebut dalam sekala besar. Dengan demikian angka kematian ikan Koi sendiri yang disebabkan oleh penyakit sangatlah tinggi karna sangat berdampak terhadap ikan Koi tersebut (Prasetya et al., 2013).

Cara penanganan penyakit Ikan Koi berbeda-beda tidak semua cara penanganannya sama, penanganan penyakit ikan Koi dapat dilakukan setelah mengetahui jenis penyakit yang dialami oleh ikan Koi dan setelah itu dilakukan proses karantina supaya tidak menyebar ke ikan lainnya (Hardiko et al., 2018). Gejala tiap penyakit ikan Koi rata-rata hampir sama yang membuat para pembudidaya dan penghobi sulit untuk menentukan jenis penyakit yang menyerang pada ikan Koi (Dewi et al., 2015). Maka dari itu solusi untuk menanggulangi permasalahan ini sangat diperlukan suatu sistem yang bisa mendiagnosis penyakit pada ikan Koi yaitu sebuah sistem pakar (Pangestu \& Tanamal, 2020). Sistem pakar dapat menjadi sebuah alat untuk membantu para pembudidaya dan penghobi ikan Koi dalam mendiagnosis penyakit yang dialami oleh ikan Koi, sehingga dapat melakukan tindakkan dengan cepat dalam penanganan penyakit ikan Koi tersebut.

Metode yang digunakan dalam perancangan sistem pakar ini adalah forward chaining dengan didukung oleh data dari seorang pakar (Wijaya \& Tanama, 2019). Forward chaining digunakan untuk merumuskan kesimpulan menjadi sebuah keputusan. Metode forward chaining sangat cocok dikarenakan kesimpulan yang sama dapat muncul meskipun rulesnya berbeda.

Di dalam penelitian ini metode forward chaining digunakan agar mendapatkan hasil dalam mendiagnosis penyakit ikan Koi dengan tingkat akurasi yang tinggi yang dapat digunakan oleh para pembudidaya dan penghobi ikan Koi yang sedang membutuhkan aplikasi tersebut. 


\section{METODE PENELITIAN}

\section{Sistem Pakar}

\section{Pengertian dan Konsep Dasar Sistem Pakar}

Menurut Rosnelly (2012) Sistem pakar adalah pemrograman komputer yang membutuhkan ilmu pengetahuan dan prosedur inferensi yang di mana 2 bagian tersebut digunakan untuk dapat menyelesaikan masalah yang membutuhkan seorang ahli atau pakar dalam memecahkan masalahnya. Oleh karena itu maka sistem pakar merupakan sistem yang dapat menyamai kemampuan dalam membuat keputusan seperti seorang pakar (Rosnelly, 2012; Saptadi \& Sebukti, 2012).

Gambar 1.

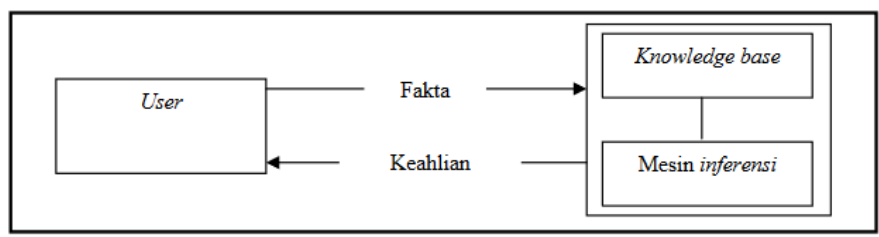

Konsep Dasar

Sistem Pakar

Gambar 2. 1 diatas menggambarkan cerminan konsep dasar pada sistem pakar, yang mana user mengantarkan suatu data pada sistem pakar guna memperoleh masukan dari ahli tersebut. Sistem pakar mempunyai 2 komponen ialah knowledge base sebagai ilmu pengetahuan dasar dari ahli serta iference engine digunakan sebagai kesimpulan.

Tujuan utama dari sistem pakar adalah mentransfer ilmu dari seorang pakar atau ahli ke dalam sebuah sistem komputer cerdas yang dapat digunakan oleh siapapun yang menggunakannya. Sistem pakar sendiri memiliki informasi yang tepercaya, seorang pakar memiliki kemampuan untuk dapat memecahkan suatu masalah dengan mudah (Saptadi \& Sebukti, 2012).

\section{Forward Chaining}

Forward chaining merupakan metode pelacakan ke depan yang diawali dengan data yang ada serta penggabungan rule yang digunakan untuk menciptakan sesuatu kesimpulan ataupun tujuan. Itu dimulai dengan serangkaian fakta yang diketahui dan menerapkan aturan untuk dihasilkan fakta baru yang di mana landasan kesimpulan tersebut cocok dengan fakta yang diketahui, dan melanjutkan proses ini hingga mencapai tujuan yang telah ditentukan sebelumnya, atau sampai tidak ada fakta lebih lanjut yang dapat diturunkan premis siapa yang cocok dengan fakta yang diketahui. Ini memeriksa fakta terhadap query atau tujuan 
yang telah ditentukan, dan menunjukkan bahwa inferensi bergerak maju dari fakta menuju tujuan (Akil, 2017; Al-Ajlan, 2015).

\section{Pakar}

Dalam penelitian ini peneliti dibantu oleh 2 orang pakar yang berprofesi sebagai dokter hewan dan pembudidaya ikan Koi. Pakar pertama adalah seorang dokter hewan yaitu Drh. Galih Anggarini Yusmarwita beliau merupakan dokter hewan di kota Surabaya. Drh. Galih Anggarini Yusmarwita pada tahun 2010 sudah menjadi dokter hewan. Awal praktek beliau di klinik cat dog veterinary di tahun 2010. Di tahun 2014 beliau berpindah tempat prakternya di k-one animal care sampai sekarang. Di tahun 2019 drh. Galih membuka klinik sendiri juga yaitu twinasa pat care yang terletak di babatan pratama wiyung. Pakar kedua adalah pembudidaya ikan Koi beliau adalah Zainal Arifin, beliau berprofesi sebagai pembudidaya ikan Koi sejak tahun 2017 di daerah Mojokerto.

\section{Desain Arsitektur}

Berikut merupakan cara kerja aplikasi dalam mendiagnosis penyakit ikan Koi yang sesuai dengan desain arsitektur:

1. User membuka aplikasi "Koi Disease"

2. kemudian, sistem akan menuju halaman home aplikasi

3. User mengklik tombol "Diagnosis Penyakit"

4. Kemudian, sistem akan menampilkan halaman daftar penyakit yang dapat dilihat penjelasan tiap penyakit yang terdapat didalam aplikasi dan juga terdapat tombol mulai diagnosis guna menuju halaman pertanyaan, pertanyaan wajib dijawab sesuai dengan kondisi yang dialami oleh ikan Koi

5. User menjawab pertanyaan yang diberikan oleh sistem

6. Sistem menerima hasil jawaban dari user

7. Lalu, sistem memproses dari hasil pertanyaan yang sudah dijawab berdasarkan metode forward chaining

8. Kemudian, sistem menampilkan hasil diagnosis dan solusi penanganan. 


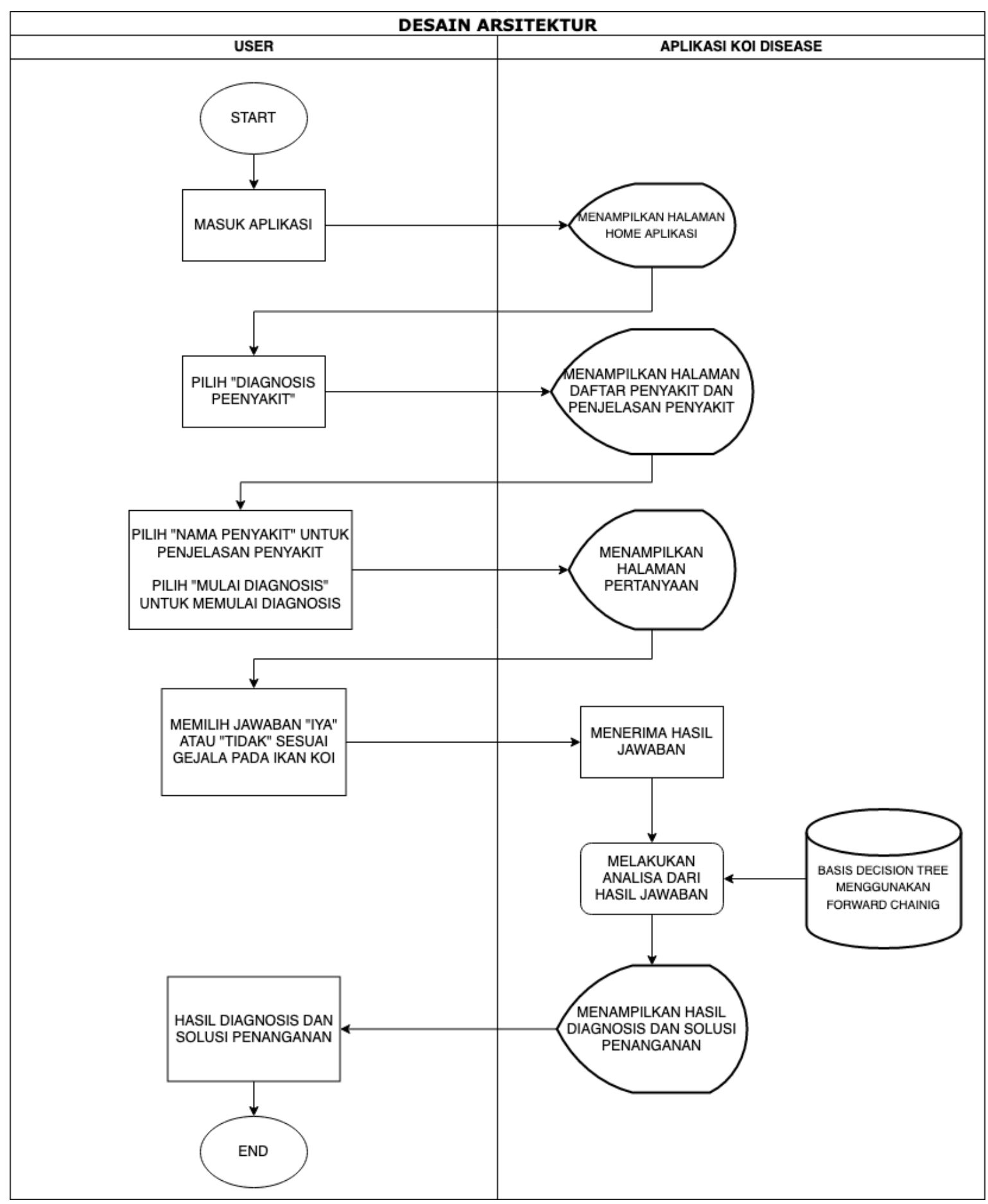

Gambar 2. Desain Arsitektur Aplikasi Koi Disease

\section{HASIL DAN PEMBAHASAN}

\section{Tahapan Implementasi}

Di tahap ini dimulai dari data wawancara yang didapat dari seorang pakar yang dijadikan menjadi sebuah decision tree. decision tree tersebut digunakan sebagai acuan yang bertujuan 
sebagai dasar pengetahuan dari aplikasi yang kemudian disusun dengan menggunakan McGoo menjadi ES-Builder kemudian diimplementasikan kedalam mobile apps yang berbasi android.

Berikut adalah pertanyaan yang telah disusun oleh peneliti untuk membuat pohon keputusan yaitu:

1. Apakah nafsu makan ikan Koi berkurang?

2. Apakah ikan Koi berdiam diri?

3. Apakah ikan Koi mengalami pembengkakan ingsang?

4. Apakah ikan Koi mengalami pembengkakan pada mulut?

5. Apakah muncul bintik putih pada bagian tubuh ikan Koi?

6. Apakah ikan Koi mengalami pembusukan pada ekor?

7. Apakah muncul kutu jangkar pada tubuh, sirip, atau ekor pada ikan Koi?

Berdasarkan pertanyaan diatas akan didapat 2 macan jawaban yaitu jawaban "IYA" dan "TIDAK" yang berkaitan dalam proses aplikasi penyakit ikan Koi. Pada saat dilakukannya proses diagnosis dari suatu pertanyaan maka pertanyaan yang ditanyakan akan berurutan sampai semua pertanyaan selesai dijawab yang dimana user menjawab sesuai kondisi yang dialami oleh ikan. Lalu setelah semua pertanyaan sudah dijawab user akan mendapatkan jawaban yang sesuai dengan gejala yang dialami dan solusi penanganan sementara.

\section{Pohon Keputusan}

\section{Gamba}

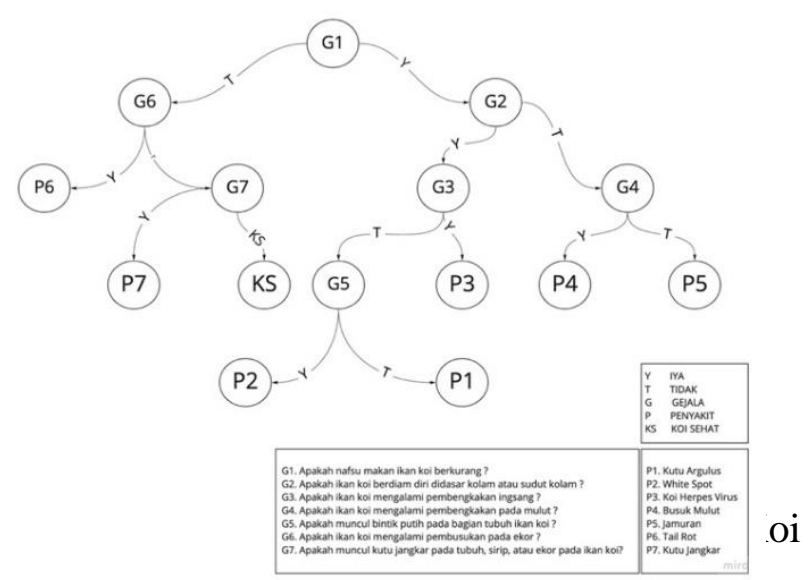

\section{User Interface}

Berikut merupakan user interface pada aplikasi Koi Disease: 


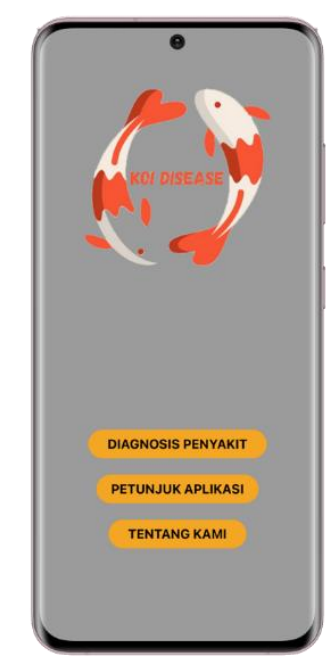

Gambar 4. Halaman Home Aplikasi Koi Disease

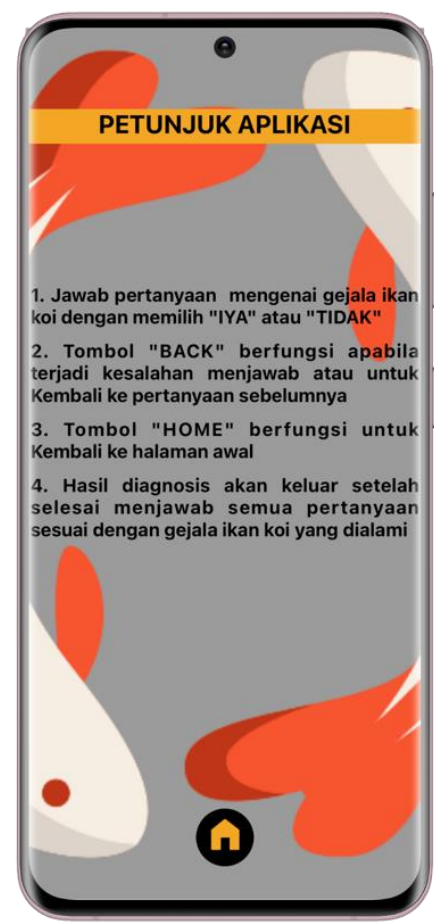

Gambar 5. Halaman Petunjuk Aplikasi Koi Disease 


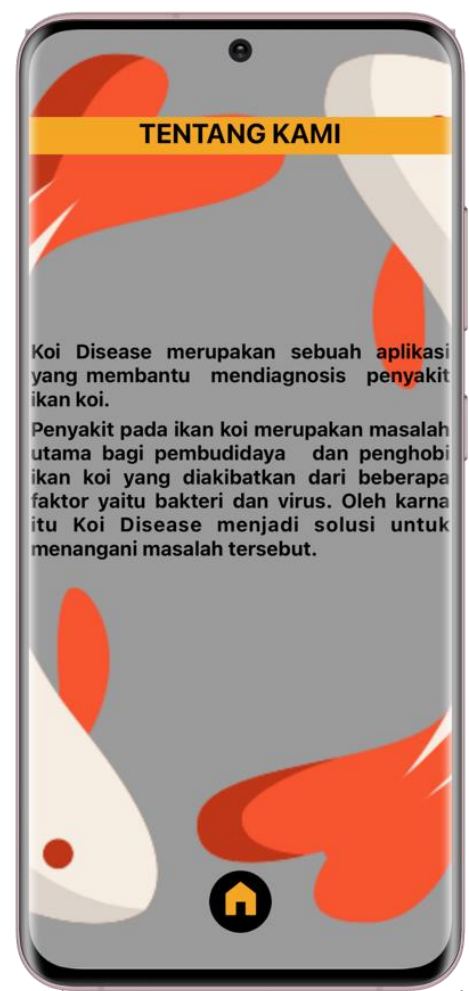

Gambar 6. Halaman Petunjuk Aplikasi Koi Disease
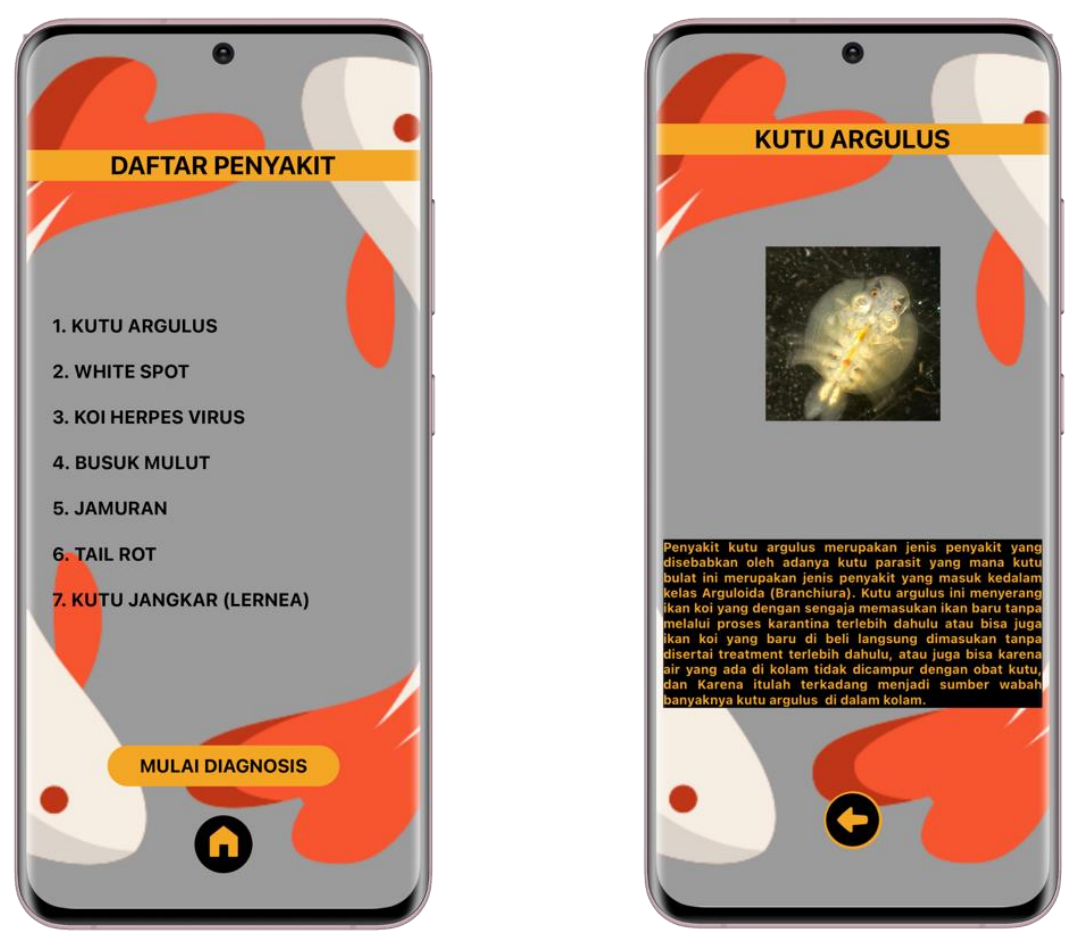

Gambar 7. Halaman Diagnosis \&Penjelasan Penyakit Aplikasi Koi Disease 


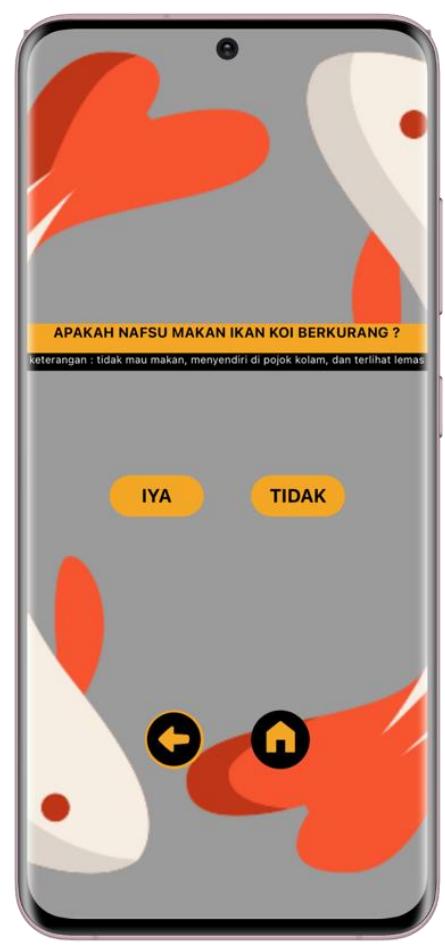

Gambar 8. Halaman Pertanyaan Penyakit Aplikasi Koi Disease

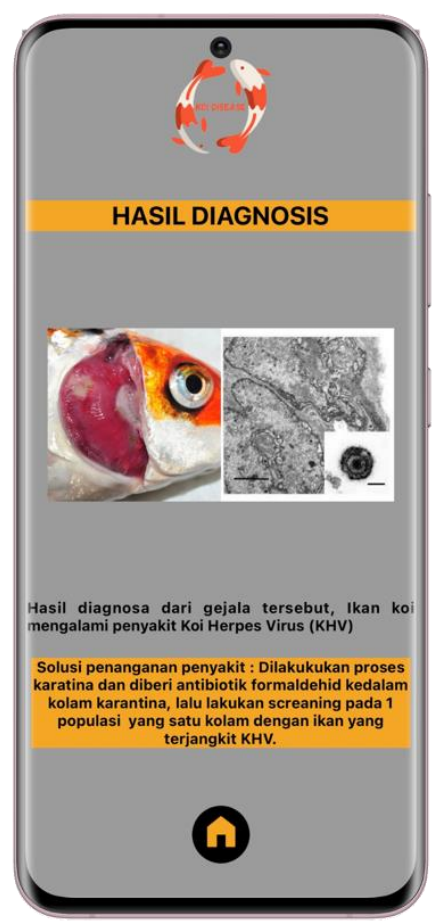

Gambar 9. Halaman Hasil Diagnosis Aplikasi Koi Disease 


\section{Uji Akurasi}

Pada tahap ini akan dilakukan pengujian keakurasian hasil dari diagnosis yang sudah dirancang sesuai dengan olahan hasil data dari wawancara bersama pakar. Berikut tabel penguji akurasi hasil diagnosis:

\section{Tabel 1. Hasil Uji Akurasi}

\begin{tabular}{lllll}
\hline No. & \multicolumn{1}{c}{ Gejala } & $\begin{array}{c}\text { Hasil Diagnosis } \\
\text { oleh Aplikasi }\end{array}$ & $\begin{array}{c}\text { Hasil Diagnosis } \\
\text { oleh Pakar }\end{array}$ & \multicolumn{1}{c}{$\begin{array}{c}\text { Hasil sesuai atau tidak } \\
\text { sesuai }\end{array}$} \\
\hline $\mathbf{1 .}$ & nafsu makan berkurang & Jamuran & jamuran & sesuai \\
\hline $\mathbf{2}$ & $\begin{array}{l}\text { nafsu makan berkurang, } \\
\text { mulut membengkak }\end{array}$ & Busuk mulut & Busuk mulut & sesuai \\
\hline $\mathbf{3}$ & $\begin{array}{l}\text { Nafsu makan berkurang, Koi Herpes } \\
\text { berdiam diri, ingsang } \\
\text { membengkak }\end{array}$ & Virus & Koi Herpes Virus & sesuai \\
\hline $\mathbf{4}$ & $\begin{array}{l}\text { Nafsu makan berkurang, } \\
\text { berdiam diri, muncul } \\
\text { bintik putih }\end{array}$ & White Spot & White Spot & sesuai \\
\hline $\mathbf{5}$ & $\begin{array}{l}\text { nafsu makan berkurang, } \\
\text { berdiam diri }\end{array}$ & Kutu bulat & Kutu bulat & sesuai \\
\hline $\mathbf{6}$ & Ekor membusuk & Tail rot & Tail rol & sesuai \\
\hline $\mathbf{7}$ & $\begin{array}{l}\text { Muncul kutu jangkar pada } \\
\text { tubuh, sirip atau ekor }\end{array}$ & Kutu jangkar & Kutu jangkar & sesuai \\
\hline
\end{tabular}

\section{Uji Testing}

Peneliti juga melakukan pengujian tehadap pengguna untuk menjalankan aplikasi Koi Disease yang bertujuan aplikasi berjalan sesuai dengan yang diharapkan. Berikut adalah tabel hasil uji testing terhadap pengguna.

\section{Tabel 2. Total Skor Uji Testing}

\begin{tabular}{|c|c|c|c|c|c|c|c|}
\hline \multirow[t]{2}{*}{ No } & \multirow[t]{2}{*}{ Pertanyaan } & \multicolumn{6}{|c|}{ Penilaian user } \\
\hline & & 1 & 2 & 3 & 4 & 5 & Skor \\
\hline 1. & Apakah aplikasi mudah digunakan? & & & & 3 & 12 & 72 \\
\hline 2. & $\begin{array}{l}\text { Apakah informasi penyakit yang diberikan } \\
\text { mudah dipahami? }\end{array}$ & & & & 4 & 11 & 71 \\
\hline 3. & $\begin{array}{l}\text { Apakah aplikasi berjalan sesuai dengan } \\
\text { fungsinya, dalam memberikan informasi hasil } \\
\text { diagnosis penyakit ikan Koi? }\end{array}$ & & & & 5 & 10 & 70 \\
\hline 4. & $\begin{array}{l}\text { Apakah fitur tampilan dalam aplikasi } \\
\text { memberikan respon yang sesuai dengan nama } \\
\text { fitur tersebut? }\end{array}$ & & & 1 & 4 & 10 & 69 \\
\hline
\end{tabular}




\section{Apakah aplikasi berguna untuk memberikan

$1 \quad 9 \quad 5 \quad 64$ diagnosis sementara pada penyakit ikan Koi?}

Kemudian peneliti melakukan Perhitungan presentase tingkat kepuasan pengguna tehadap penggunaan aplikasi.

Tabel 3. Hasil Persentase Tingkat Kepuasan Pengguna

\begin{tabular}{llll}
\hline No. & \multicolumn{1}{c}{ Pertanyaan } & Nilai & Keterangan \\
\hline 1. & Apakah aplikasi mudah digunakan? & $96 \%$ & Sangat Setuju \\
\hline 2. & Apakah informasi penyakit yang diberikan mudah & $94 \%$ & Sangat Setuju \\
& dipahami? & \\
\hline 3. & Apakah aplikasi berjalan sesuai dengan fungsinya, & $93 \%$ & \\
& dalam memberikan informasi hasil diagnosis penyakit & \\
& ikan Koi? & & Sangat Setuju \\
\hline 4. Apakah fitur tampilan dalam aplikasi memberikan & $92 \%$ & Sangat Setuju \\
& respon yang sesuai dengan nama fitur tersebut? & \\
\hline 5. Apakah aplikasi berguna untuk memberikan diagnosis & $85 \%$ & \\
& sementara pada penyakit ikan Koi?
\end{tabular}

\section{KESIMPULAN}

Berdasarkan proses penelitian yang sudah dilakukan sebelumnya, maka didapatkan sebuah kesimpulan dari hasil penelitian sebagai berikut:

1. Perancangan aplikasi berbasis mobile apps yang dilakukan oleh peneliti dibuat berdasarkan dasar pengetahuan yang diperoleh dari pohon keputusan yang sudah di validasi serta diterapkan dalam apps builder Thunkable menggunakan metode forward chaining yang berfungsi untuk mendiagnosis penyakit ikan Koi dengan berdasarkan hasil wawancara dan pengamatan yang dilakukan bersama pakar.

2. Hasil dari Analisa yang sudah diukur menggunakan skala linkert dapat disimpulkan bahwa pengguna menyetujuan aplikasi Koi Disease berfungsi dengan baik. 


\section{REFERENSI}

Akil, I. (2017). Analisa Efektifitas Metode Forward Chaining Dan Backward Chaining Pada Sistem Pakar. Jurnal Pilar Nusa Mandiri, 13.

Al-Ajlan, A. (2015). The Comparison between Forward and Backward Chaining. International Journal of Machine Learning and Computing, 5, 2nd ser.

Dewi, P. S., Lestari, R. D., \& Lestari, R. T. (2015). Sistem Pakar Diagnosis Penyakit Ikan Koidengan Metode Bayes. Jurnal Ilmiah Komputer Dan Informatika (Komputa), 4(1), 25-32.

Hardiko, Y. J., Hidayat, N., \& Cholissodin, I. (2018). Diagnosis Penyakit Ikan Koi Menggunakan Metode Naive Bayes Classifier. Jurnal Pengembangan Teknologi Informasi dan Ilmu Komputer Vol. 2, No. 11, November 2018, hlm. 5310-5316, 2(11), 5310-5316.

Kusrini, E., Cindelaras, S., \& Prasetio, A. B. (2015). Pengembangan Budidaya Ikan Hias Koi (Cyprinus Carpio) Lokaldi Balai Penelitian Dan Pengembangan Budidaya Ikan Hias Depok. Media Akuakultur, 10(2), 71-78.

Pangestu, A. S., \& Tanamal, R. (2020). Rancang Bangun Aplikasi Sistem Pakar Berbasis Mobile Untuk Mendiagnosis Penyakit Kulit Pada Kucing Persia. Teknika, 9(2), 81-87.

Prasetya, N., Subekti, S., \& Kismiyati. (2013). Prevalensi Ektoparasit Yang Menyerang Benih Ikan Koi (Cyprinus Carpio) Di Bursa Ikan Hias Surabaya. Jurnal Ilmiah Perikanan dan Kelautan, 5(1).

Rosnelly, R. (2012). Sistem Pakar Konsep Dan Teori. Yogyakarta: Andi.

Saptadi, T. S., \& Sebukita, V. S. (2012). Pengambilan Keputusan Dalam Penerimaan Karyawan Bank Dengan Pendekatan Terstruktur Berbasis Sistem Pakar. Jurnal Teknologi Komputer dan Informatika, 81.

Wijaya, B., \& Tanama, R. (2019). Rancang Bangun Aplikasi Sistem Pakar Berbasis Android Menggunakan Metode Forward Chaining Untuk Mendiagnosis Kerusakan Pada HardwareLaptop. Teknika, 8(1), 25-35.

Yanuhar, U., Musa, M., \& Wuragil, D. K. (2019). Pelatihan Dan Pendampingan Manajemen Kualitas Air Dan Kesehatan Pada Budidaya Ikan Koi (Cyprinus Carpio). Jurnal Karinov, 2(1), 69-74. 